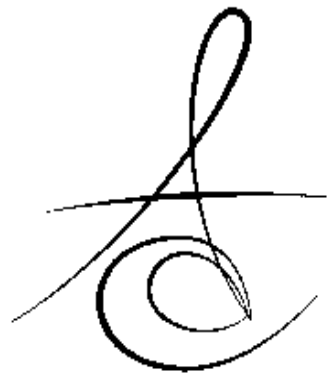

\title{
THE RELATIONSHIP BETWEEN PERIODONTAL DISEASE AND ALZHEIMER'S DISEASE
}

\author{
PERİODONTAL HASTALIKLA ALZHEİMER HASTALIĞI ARASINDAKİ İLİşKi்
}

Prof. Dr. Recep ORBAK*

Araş. Gör. Dt. Melike ÖZTÜRK*

Makale Kodu/Article code: 1778

Makale Gönderilme tarihi: 14.07 .2014

Kabul Tarihi: 24.11.2014

\section{ABSTRACT}

Alzheimer's disease(AD) is a neurodegenerative disease that effects elder people. As the age increases, the prevalance of Alzheimer's disease also raises. As $A D$, periodontitis is seen more often in elder people. Periodontal disease has been associated with some systemical diseases such as cardiovascular diasease(CVS), diabetes mellitus, rheumatoid arthritis and preterm birth. Latterly, it has been investigated if there is a connection between Alzheimer's diasease. This review's aim is, inspecting if the periodontal disease contributes to Alzheimer's disease at literacy. Keywords: Alzheimer's disease, inflammation, periodontal disease, periodontitis

\section{ÖZET}

Alzheimer hastalığı yaşlı insanları etkileyen nörodejeneratif bir hastalıktır. Bireyin yaşı arttıkça, Alzheimer hastalığının prevalansı da artmaktadır. Alzheimer hastalığında görüldüğü gibi, periodontal hastalık da yaşı bireylerde daha çok görülmektedir. Periodontal hastalık kardiovasküler hastalıklar, diyabet, romatoid artrit ve erken doğum gibi sistemik hastalıklarla bağlantılıdır. Son zamanlarda, periodontal hastalığın Alzheimer hastalığıyla ilişkisinin olup olmadığı araştırımaktadır. Bu derlemenin amacı, literatür bilgileri ışığında periodontal hastalığın Alzheimer hastalığına neden olup olmadığını incelemektir.

Anahtar Kelimeler: Alzheimer hastalığı,enflamasyon, periodontal hastalık, periodontitis

\section{INTRODUCTION}

Periodontal infections consist of due to the interaction between microbial film and host defenses. Gram negative anaerobes in mature biofilm stimulates host responses ${ }^{1}$. Host response recruits neutrophils, other cells and their products of inflammatory mediators which are cytokines and prostaglandins ${ }^{2}$. Recent studies show that host inflammatory response can be more crucial than bacterial biofilm formation than originally thought ${ }^{3}$. Continued production of inflammatory mediators and the interactions at host response, results in the eradication of alveolar bone and connective tissue ${ }^{4,5}$. Endotoxins, which are a lipopolysaccharide at cell wall of Gram negative bacteria start the inflammatory events of periodontal disease. Endotoxins stimulate some inflammatory cells like monocytes, macrophages, fibroblasts and T cells. By this way, cytokines and prostaglandins are secreted. The most crucial cytokines that are associated with periodontal disease, are interleukin1(IL-1), interleukin-6(IL-6), interleukin-8(IL-8) and tumor necrotizing factor-alpha(TNF-a). IL-1 and TNF-a induce cells to produce CRP. In a number of studies, proinflammatory cytokines in gingival crevicular fluid and in inflamed gingival tissues were reported in a high amount at patients with active periodontal disease to the healthy group ${ }^{6}$. In another research, acute phase proteins, including CRP, has been found at increased levels in gingival crevicular fluid ${ }^{7,8}$. It is thought that the inflammatory mediators which are produced locally may get into the systemic circulation and leads to increased serum levels of cytokines and

*Atatürk Üniversitesi Diş Hekimliği Fakültesi Periodontoloji AD

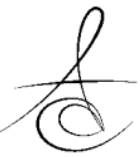


acute phase reactants ${ }^{9}$. Moreover, daily bacteremias can ocur by even after toothbrushing, flossing and after dental procedures ${ }^{10,11}$. It is suspected that patients with periodontal disease may experience transient bacteremia multiple times per day ${ }^{10,11,12}$.

The systemic inflammation that is induced by periodontitis has also been suggested as a riskfactor for some other diseases such as stroke ${ }^{13}$, cardiovascular disease ${ }^{9}$, diabetes complications ${ }^{14}$ and preterm birth $^{15}$. Genco et al $^{9}$ found that oral bacteria including P.gingivalis and Streptococcus sanguis has a direct effect on induction of platelet activation and aggregation that can lead to atheroma formation and thrombosis. Genco and colleagues ${ }^{9}$ also demonstrated that having heart attack increases with the severity of periodontitis.

Investigations about the correlance of diabetes and preterm birth with periodontal disease has also been reported. Offenbacher and colleagues ${ }^{16}$ found that mothers who have severe periodontal disease had 7.5 fold increase in the risk of having preterm, low birth weight baby. Moreover, it has reported people with poorly controlled diabetes improved metabolic control after periodontal therapy ${ }^{17}$. In addition, there are some studies about the linkage of periodontitis to rheumatoid arthritis. Rosenstein et $\mathrm{al}^{18}$ hypothesize that patients with severe periodontal disease display autoimmune responses like production of rheumatoid factor. Given the evidence for the relationship between periodontal disease and other systemic diseases, it is reasonable to suggest treatment of periodontitis does not only solve the intraorally problems, but also helps to maintain the systemic health of people.

The Characteristics of Alzheimer's Disease and its Relationship between Periodontitis

Alzheimer's disease which was first described by Alois Alzheimer in $1907^{19}$ is the main cause of dementia in elderly people. Other types of dementias are vascular dementia, dementia associated with Lewy bodies, frontotemporal dementia, Creutzfeld-Jakob disease and Parkinson's disease. Between the age of 65 to 74 years, the prevalance is nearly $3 \%$. However, this ratio increases by age and gets $19 \%$ between 75 and 84 years and $47 \%$ at older than 85 years $^{20}$. AD is diagnosed more often in women, about two-thirds of $A D$ cases $^{21}$. 8-10 years after the first identifiable symptoms, the clinical course of $A D$ can be seen but it can also be as long as 20 years $^{22}$. Alzheimer's disease can be diagnosed with Mini Mental State Examination $^{23}$ and Clinical Dementia Rating Scale(CDR) ${ }^{24,25}$.

The characteristics of this neurodegenerative disease are extracellular $\beta$-amyloid peptide which also often referred to as neuritic plaques or senile plaques, hyperphosphorylated tau protein(neurofibrillary tangles) and neuronal or synaptic loss ${ }^{26,27}$. The neuronal dysfunction affects cholinergic synaptic transmission that enhances attention and learning processes $^{20}$. AD is severe when it progresses and contributes to impairment of cognitive skills ${ }^{27}$. As it becomes severe, memory loss, gradual disorientation in time and space, language problems, inability to learn new things and difficulties when performing daily activities occur ${ }^{27}$ In severe phase of $A D$, cognitive abilities are almost impaired, therefore complete loss of recent and remote memory happens ${ }^{27}$. AD patients have difficulties in motor skills, so they are at great risk for developing medical complications and stomatological disorders when they perform oral and personal care. For this reason, people with severe $A D$ need caregivers ${ }^{28}$.

$A D$ has multifactorial etiology like family history, apolipoprotein E, advanced age, low educational level, cardiovascular disease, head trauma, Down's syndrome and female gender ${ }^{26}$. However, the greatest risk factor accounts for older age and family history of disease. Neuropathological cascade of this disease is still unknown. Latterly, the major cause of $A D$ is considered as involvement of oxidative stress in which free radical levels excel antioxidant defen$\operatorname{ses}^{29,30}$. Aging and accumulation of amyloid- $\beta$ proteins occur due to the progressive oxidative modification of proteins ${ }^{31-33}$. It is hypothesized that $A D$ is triggered by the formation of $A \beta$ plaques ${ }^{34}$. Amyloid peptides activate microglial cells ${ }^{35,36}$ which are distributed throughout the grey and white matter of nervous system. Microglial cells are specialized immune cells, related to macrophages and they can attack and phagocyte when activated. Activated microglial cells secrete upregulated inflammatory mediators, migrate to inflammatory site and exhibit scavenger responses to abnormal protein accumulations and damaged tissue. This process can be seen abundantly in pathologically vulnerable regions of $A D$ brain.

After the treatment of patients who have $A D$, they improve cognitive and functional performance ${ }^{28}$, 
decrease behavioral disturbances ${ }^{37}$, stabilize mood $^{20}$, delay loss of daily living activities and improve the life quality. In older people, life quality and general health is enhanced by maintaining natural teeth and having well-fitted prosthesis ${ }^{38}$. Thinking of $A D$ patients who have decreased cognitive and motor abilities, it is very difficult to enhance the adequate biofilm control and oral hygien ${ }^{39}$. Subject with AD can forget to remove their prosthesis which can leads to accumulation of food debris and dental biofilm on their own teeth ${ }^{20}$. At this point, important duty comes to caregivers. However, most of caregivers are not educated about maintaining the oral hygiene. So, they should be informed about it. In a study ${ }^{40}$, the comparison between healty and $A D$ group, the number of natural teeth, number of decayed, missing and filled teeth(DMTF), oral health index(OHI),removable prosthesis conditions, oral pathologies and General Oral Health Assesment Index(GOHAI) were investigated. GOHAI values found similar in both groups. Subjects with AD had higher age, DMTF,OHI, number of pathologies. Patients with $A D$ should be recalled frequently for preventing the progression of periodontal disease.

The increased inflammatory mediators at

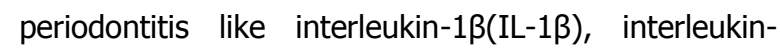
6(IL-6) and Tumor Necrotizing Factor-a(TNF-a) participate at molecular pathways that leads to neurodegeneration ${ }^{41,42}$. It is demonstrated that one of the periodontal pathogens, Treponema species (including Treponema denticola) has been present at higher frequency in the brain of $A D$ patients compared to healthy subjects ${ }^{43}$. Stein et $\mathrm{al}^{44}$ reported that antibody levels of F.nucleatum and P.intermedia were significantly increased at patients with $A D$ compared to control group. In another research, it is reported that high levels of serum TNF-a had fourfold increase in cognitive decline when compared to control group ${ }^{45}$. Noble et $\mathrm{al}^{46}$ found that patients who have high levels of serum antibodies to periodontal bacteria have lower scored on delayed word recall and calculation tasks. Bretz et $\mathrm{al}^{47}$ investigated the IL- 6 serum level at periodontal disease patients. The results were significantly higher than the control group. This result is very prerequisite because IL- 6 is associated with local production of amyloid proteins $s^{48}$.

The number of pathogenic bacteria that reaches the systemic circulation is low at people with good oral hygiene. On the other hand, people with periodontal disease, this ratio increases twofold to tenfold ${ }^{49}$. In a study, it has been reported that $\% 55$ of patients with severe periodontal diseases have positive cultures of oral bacteria in arterial blood ${ }^{50}$.

At the end of 19th century, it was suggested that brain infections and abscesses were resulted from oral bacteria's lodgement at weak points in brain ${ }^{51}$. In fact, there are some researches about the relationship between brain infections and oral bacteria specifically linked to periodontal pathogens ${ }^{52}$. It has been demonstrated that Actinobacillus actinomyc etemcomitans is associated with coagulative necrosis of cortical cells and white matter ${ }^{53}$.

Recent researches have shown brain receptors are specific for gram-negative bacteria ${ }^{54}$, which are the main flora of periodontal disease. Latterly, gramnegative bacteria have been connected to Alzheimer's etiology, especially late-onset sporadic $A D^{55}$. In another study, 17 of 19 post mortem Alzheimer's brains were affected by gram-negative Chlamydia pneumonia, while control groups were not affected ${ }^{56}$. Another post mortem research has reported that 14 of 16 Alzheimer's brains contain oral Treponema, but only 4 of 18 control brains include them ${ }^{57}$. Those studies show that, pathogenic oral bacteria reach bloodstream and after reaching brain, they start or progress existing lesions.

Summarizing all of those researches, it is reasonable to suggest neuropathological changes can occur due to the continued exposure of inflammatory mediators that are caused by periodontal pathogen $\mathrm{s}^{58}$.

\section{CONCLUSION}

There are several studies about the relationship of Alzheimer's disease and periodontal disease recently. The etiology of $A D$ is still not known but the most important risk factor is the inflammation at brain. Periodontal disease is also investigated if it is one of the reasons of inflammation at brain by its antienflammatory cytokines. This review's aim is to inform the connection between $A D$ and periodontal disease with the studies at literacy. 


\section{REFERENCES}

1. Darveau R, Tanner A, Page RC. The microbial challenge in periodontitis. Periodontol 2000 2000;14:1:12-32.

2. Lamster IB, Novak MJ. Host mediators in gingival crevicular fluid: implications for the pathogenesis of periodontal disease. Crit Rev Oral Biol Med 1992;3:1:31-60.

3. Van Dyke, TE, Kornman KS. Inflammation and factors that may regulate inflammatory response. J. Periodontol 2008;79:8:1503-7.

4. Page RC, Offenbacher S, Schroeder HE. Advances in the pathogenesis of periodontitis: summary of developments, clinical implications and future directions. Periodontol 2000 1997; 14:1:216-48.

5. Page RC. The role of inflammatory mediators in the pathogenesis of periodontal disease. J Periodontal Res 1991;26:3:230-42.

6. Gamonal J, Acevedo A, Bascones A, Jorge O, Silva A. Levels of interleukin- $1 \beta,-8$, and-10 and RANTES in gingival crevicular fluid and cell populations in adult periodontitis patients and the effect of periodontal treatment. Journal of periodontology2000;71:10:1535-45.

7. Tüter $G$,Kurtis $B$,Serdar M.Evaluation of gingival crevicular fluid and serum levels of high-sensitivity C-Reactive protein in chronic periodontits patients with or without coronary artery disease.J Periodontol 2007;78:12:2319-24.

8. Noack B,Genco RJ,Trevisan M,Grossi S,Zambon $J$ J,Nardin E.Periodontal infections contribute to elevated systemic C-reactive protein level.J Periodontol 2000 2001;72,1221-7.

9. Genco R,Offenbacher S, Beck J.Periodontal disease and cardiovascular disease. JADA 2002;133,145225.

10. Loos BG. Systemic markers of inflammation in periodontitis. J Periodontol 2005, 76:2106-15.

11. Forner $L$, Larsen $T$, Kilian $M$. Incidence of bacteremia after chewing, tooth brushing, and scaling in individuals with periodonta inflammation. J Clin Periodontol 2006;33:6:401-7.

12. Li X, Kolltveit KM, Tronstad L. Systemic diseases caused by oral infection. Clin Microbiol Rev 2000; 13:4:547-58.
13. Grau AJ, Becher H, Ziegler CM, Lichy C, Buggle F, Kaiser C. Periodontal disease as a risk factor for ischemic stroke. Stroke 2004;35:2:496-501.

14. Grossi Sara G, Robert J Genco. Periodontal Disease and Diabetes Mellitus: A Two-Way Relationship. Annals of periodontology 1998;3:1: 51-61.

15. Lopez NJ, Smith PC, Gutierrez J. Higher risk of preterm birth and low birth weight in women with periodontal disease. J Dent Res 2002; 81:1:58-63.

16. Offenbacher S, Katz V, Fertik G,Collins J,Boyd D,Maynor G,McKaig R,Beck J.Periodontal infection as a possible risk factor for preterm low birth weight.Periodontol 2000 1996;67:10:1103-13.

17. Kuran M, Arpak N, Ünsal E, Erdoğan MF.The effect of improved periodontal health on metabolic control in type 2 diabetes mellitus. J Clin Periodontol 2005;32:266-72.

18. Rosenstein E.D,Greenwald R.A,Kushner L.J,Weissmann G.Hypothesis:The humoral immune response to oral bacteria provides a stimulus fort he development of rheumatoid arthritis. Inflammation 2004;28:6:311-8.

19. Alzheimer A. Uber eine eigenartige Erkrankung der Hirnrinde. Allg Z Psychiat ui Grenzbeg 1907; 64:164-8.

20. Friedlander AH, Norman DC, Mahler ME, Norman KM, Yagiela JA. Alzheimer's disease: psychopathology, medical management and dental implications. J Am Dent Assoc 2006;137:1240-51.

21. Kocaelli $H$, Yaltirik $M$, Yargic LI, Ozbas $H$. Alzheimer's disease and dental management. Oral Surg Oral Med Oral Pathol Oral Radiol Endod 2002;93:521-4.

22. Larson EB, Shadlen MF, Wang $L$, et al. Survival after initial diagnosis of Alzheimer's disease. Ann Intern Med 2004;140:501-9.

23. Folstein MF, Folstein SE, McHugh PR."Mini-mental state" A practical method for grading the cognitive state of patients for the clinician. J Psychiatr Res 1975; 12:189-98.

24. Berg L. Clinical Demential Rating (CDR). Psychopharmacol Bull 1988; 24:637-9.

25. Morris JC. The Clinical Dementia Rating (CDR): current version and scoring rules. Neurology 1993; 43:2412-4.

26. Reiman EM, Caselli RJ. Alzheimer's disease. Maturitas 1999;15:185-200.

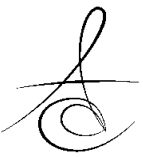


27. Ghezzi EM, Ship JA. Dementia and oral health. Oral Surg Oral Med Oral Pathol Oral Radiol Endod 2000; 89:1:2-5.

28. Machado DS, FRANK J,Abdala A, De Abreu Soares E. Fatores dietéticos relacionados à doença de Alzheimer.Publicação Oficial da Sociedade Brasileira de Nutrição Parenteral e Enteral (SBNPE) e da Federación Latinoamericana de Nutrición Parenteral y Enteral (FELANPE) 2006;4005:3:2527.

29. Perry G, Cash AD, Smith MA. Alzheimer's disease and oxidative stress. J Biomed Biotechnol. 2002;2:120-3.

30. Perry G, Taddeo MA, Nunomura A. Comparative biology and pathology of oxidative stress in Alzheimer's and other neurodegenerative diseases: beyond damage and response. Comp Biochem Physiol C Toxicol Pharmacol 2002;133:507-13.

31. Lorenzo A, Yankner BA. Beta-anyloid Neurotoxicity requires fibril formation and is inhibited by congo red. Proc Natl Acad Sci USA 1994;91:12243-7.

32. Shigenaga MK, Hagen TM, Ames BN. Oxidative damage and mitochondrial decay in aging. Proc Natl Acad Sci USA 1994;91:10771-8.

33. Yatin $S M$, Varadarajan $S$, Link $C D$, et al. In vitro and in vivo oxidative stress associated with Alzheimer's amyloid beta-peptide (1-42). Neurobiol Aging. 1999;20:325-330; discussion 339-42.

34. Walsh DM, Selkoe DJ. Deciphering the molecular basis of memory failure in Alzheimer's disease. Neuron 2004;44:1:181-93.

35. Barger SW, Harmon AD. Microglial activation by Alzheimer amyloid precursor protein and modulation by apolipoprotein E. Nature 1997; 388: 6645:878-81.

36. Dickson DW, Lee SC, Mattiace LA, et al. Microglia and cytokines in neurological disease, with special reference to AIDS and Alzheimer's disease. Glia 1993; 7:75-83.

37. Cummings JL. Alzheimer's disease. N Engl J Med 2004; 351:56-67.

38. Montenegro FLB, Marchini L, Brunetti RF, Manetta CE. A importância do bom funcionamento do sistema mastigatório para o processo digestivo dos idosos. Rev Kairós 2007;10:245-57.

39. Henry RG, Wekstein DR. Providing dental care for patients diagnosed with Alzheimer's disease. Dent Clin North Am 1997;41:915-43.
40. Rodrigues Riberio G, Costa Riani JL, Bovi Ambrosaro GM, Rodirgues Garcia RCM. Oral health of the elderly with Alzheimer's disease.Oral Surg Oral Med Oral Pathol Oral Radiol 2012;114:338-43.

41. Akiyama $H$, Arai T, Kondo H, Tanno E, Haga C, Ikeda $\mathrm{K}$. Cell mediators of inflammation in the Alzheimer disease brain. Alzheimer Dis. Assoc. Disord 2000; 14: 47-53.

42. McGeer PL, Rogers J, McGeer EG. Inflammation, anti-inflammatory agents and Alzheimer disease: the last 12 years. J. Alzheimers Dis 2006;9:271-6.

43. Miklossy J. Alzheimer's disease-a spirochetosis? Neuroreport 1993;4: 1069.

44. Stein PS,Steffen MJ,Smith C,Jicha G,Ebersole JL,Abner E,Dawson D.Serum antibodies to periodontal pathogens are a risk factor for Alzheimer's disease.Alzheimer's\&Dementia 2012; 8,196-203.

45. Holmes C, Cunningham C, Zotova E, Woolford J, Dean C, Kerr S, et al. Systemic inflammation and disease progression in Alzheimer's disease. Neurology 2009;73:768-74.

46. Noble JM, Borrell LN, Papapanou PN, Elkind MSV, Scarmeas Wright CB. Periodontitis is associated with cognitive impairment among older adults: analysis of NHANES -III. J Neurol Neurosurg Psychiatry 2009;80:1206-11.

47. Bretz WA, Weyant RJ,Corby PM,Ren D, Weissfeld L, Kritchevsky SB,Harris T,Kurella M,Satterfield S,Visser M,Newman AB.Systemic inflammatory markers,periodontal disease, and periodontal infections in an elderly population.J Am Geritr Soc 2005; 53:1532-7.

48. Bo RD,Angeretti N,Lucca E,Simoni MGD,Forloni G.Reciprocal control of inflammatory cytokines, IL1 and IL-6, and $\beta$-amyloid productions in cultures.Neuroscience Letters 1995;188:1:70-4.

49. Leenstra TS, van Saene JJ, van Saene HK, Martin MV. Oral endotoxin in healthy adults. Oral Surgery, Oral Medicine, Oral Pathology, Oral Radiology, and Endodontology 1996;82:6:637-43.

50. Loos BG, Craandijk J, Hoek FJ, Dillen PMW, Velden UVD. Elevation of systemic markers related to cardiovascular diseases in the peripheral blood of periodontitis patients. Journal of periodontology 2000;71:10:1528-34. 
51. Gardiner SS. Actinomycosis of the head and neck. Australian and New Zealand Journal of Surgery 1936;6:2:186-224.

52. Gendron R, Grenier D, Maheu-Robert LF. The oral cavity as a reservoir of bacterial pathogens for focal infections. Microbes and infection 2000; 2:8:897-906.

53. Stein PS, Scheff S, Dawson DR. Alzheimer's disease and periodontal disease: mechanisms underlying a potential bidirectional relationship. Grand Rounds Oral-Sys Med 2006;1:3:14-24.

54. Laflamme N,Rivest S. Toll-like receptor 4:the missing link of the cerebral innate immune response triggered by circulating gram-negative bacterial cell wall components. The FASEB Journal 2001; 15:1:155-63.

55. Holmes C,Cotterell D. Role of infection in the pathogenesis of Alzhemer's disease. CNS Drugs 2009;23:12:993-1002.

56. Balin BJ,Gerard HC, Arking EJ, Appelt DM, Branigan PJ, Abrams JT, Whittum-Hudson JA, Hudson AP. Identification and localization of Chlamydia pneumoniae in the Alzheimer's brain. Med Microbiol Immunol 1998;187:1:23-42.

57. Riviere GR, Riviere KH, Smith KS. Molecular and immunological evidence of oral Treponema in the human brain and their association with Alzheimer's disease. Oral microbiology and immunology 2002; 17:2:113-8.

58. Kamer AR,Craig RG,Dasanayake AP,Brys M,Glodzik-Sobanska L,Leon MJD.Inflammation and Alzheimer's disease: possible role of periodontal disease.Alzheimer's\&Dementia 2008;4,242-50.

\section{Yazışma Adresi}

Arş.Gör.Dt.Melike Öztürk

Atatürk Üniversitesi

Diş Hekimliği Fakültesi

Periodontoloji Anabilim Dalı,

Yakutiye Erzurum

TIf: 05057624562

e-mail: dtmelikeozturk@hotmail.com 